\title{
Inhibition of the Ubiquitin-Proteasome System by Natural Products for Cancer Therapy
}

Authors

Affiliations
Sachiko Tsukamoto ${ }^{1}$, Hideyoshi Yokosawa ${ }^{2}$

${ }^{1}$ Graduate School of Pharmaceutical Sciences, Kumamoto University, Kumamoto, Japan

2 School of Pharmacy, Aichi Gakuin University, Nagoya, Japan

\begin{abstract}
Key words
natural products

- ubiquitin

- proteasome

- cancer therapy

- drug discovery

- targeted therapy
\end{abstract}

received Dec. 19, 2009 revised January 10, 2010 accepted January 22, 2010

Bibliography

DOI http://dx.doi.org/

10.1055/s-0029-1240901

Published online February 25,

2010

Planta Med 2010; 76 :

1064-1074 ๑ Georg Thieme

Verlag KG Stuttgart · New York . ISSN 0032-0943

Correspondence

Prof. Sachiko Tsukamoto, Ph.D.

Graduate School of

Pharmaceutical Sciences

Kumamoto University

5-1 Oe-honmachi

862-0973 Kumamoto

Japan

Phone: +81963714380

Fax: +81963627799

sachiko@kumamoto-u.ac.jp

\section{Abstract}

The ubiquitin-proteasome system plays a critical role in selective protein degradation and regulates almost all cellular events such as cell cycle progression, signal transduction, cell death, immune responses, metabolism, protein quality control, development, and neuronal function. The recent approval of bortezomib, a synthetic proteasome inhibitor, for the treatment of re-

\section{The Ubiquitin-Proteasome System}

$\nabla$

Regulated protein degradation via the ubiquitinproteasome system ( $\mathbf{F i g . 1}$ ) is an essential aspect of cell signaling pathways, functioning from cell-cycle control and transcription to development [1-3]. In the ubiquitin-proteasome system, the client proteins are ubiquitinated by the ubiquitin system and degraded by the $26 \mathrm{~S}$ proteasome in an ATP-dependent manner. Ubiquitin is composed of 76 amino acids and attaches to a client protein (ubiquitination) prior to degradation. In the ubiquitin system, ubiquitination requires the sequential actions of three enzymes, ubiquitin-activating enzyme (E1), ubiquitin-conjugating enzyme (E2), and ubiquitin-protein ligase (E3), which results in the formation of the polyubiquitin chain. Then, the polyubiquitin chain, tagged to the client protein, is recognized by the $26 \mathrm{~S}$ proteasome, an intracellular high-molecular weight protease subunit complex [1-6]. The $26 \mathrm{~S}$ proteasome consists of two subcomplexes, the 20S core particle (also known as the 20S proteasome) and the $19 \mathrm{~S}$ regulatory particle ( $\bullet$ Fig. 1 ), and the protein portion of a client protein is degraded by the proteolytic active sites in a cavity of the 20S proteasome. The $20 \mathrm{~S}$ proteasome is classified as a threonine protease that contains two pairs of three different catalytic sites. The $\beta 1, \beta 2$, and $\beta 5$ subunits contain catalytic sites with caspase-like, lapsed multiple myeloma has opened the way to the discovery of drugs targeting the proteasome and ubiquitinating and deubiquitinating enzymes as well as the delivery system. To date, various synthetic and natural products have been reported to inhibit the components of the ubiquitin-proteasome system. Here, we review natural products targeting the ubiquitin-proteasome system as well as synthetic compounds with potent inhibitory effects. 


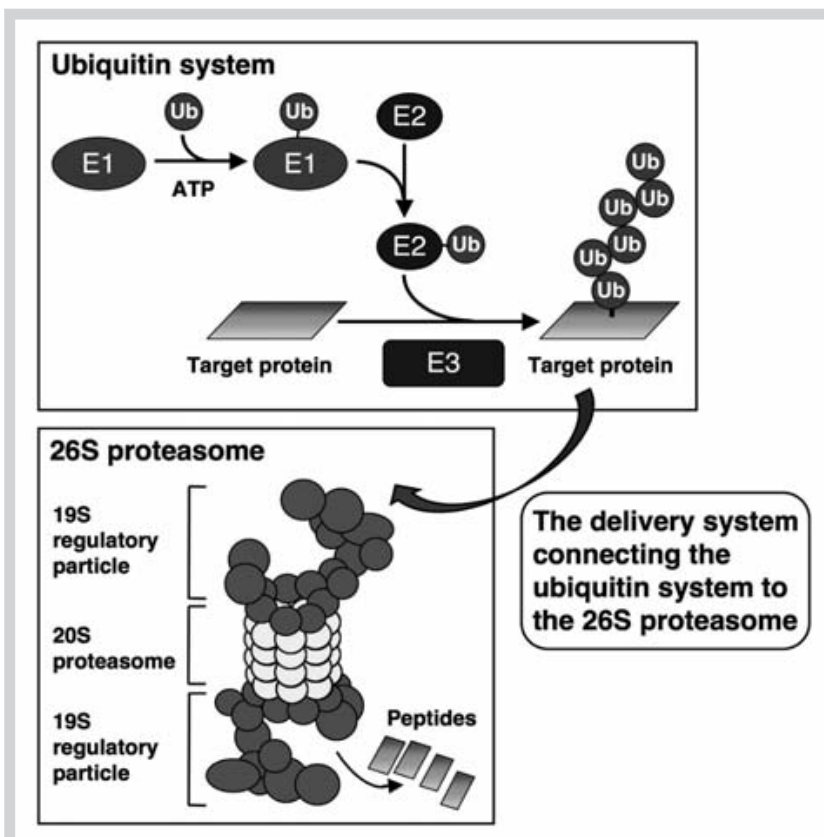

Fig. 1 Schematic diagram of the ubiquitin-proteasome system. This system consists of the ubiquitin system, the 265 proteasome, and the delivery system. Ub, ubiquitin; E1, Ub-activating enzyme; E2, Ub-conjugating enzyme; E3, Ub-protein ligase.

\section{Targeting the 205 Proteasome \\ $\nabla$}

\section{Inhibitory mechanisms of proteasome inhibitors}

Proteasome inhibitors show antitumor activity against various tumor cells that are resistant to conventional chemotherapeutic agents. Structurally diverse proteasome inhibitors have been developed by chemical synthesis and also by searching natural sources and chemical libraries as drugs for the clinical treatment of cancer and also as molecular tools for the investigation of cellular events. To date, various synthetic peptides including MG132 (Z-Leu-Leu-Leu-al, 1) (๑ Fig. 2) [7] and bortezomib (PS-341, Velcade $^{\circledR}, 2$ ) (๑ Fig. 3) [8,9], and natural products including salinosporamide A (NPI-0052, 3) ( $\nabla$ Fig. 4) [10] have been reported to inhibit proteasomal activity. Bortezomib (2), a synthetic proteasome inhibitor developed by Millennium Pharmaceuticals, Inc., was approved for myeloma therapy in the United States in 2003, which strongly indicates that the proteasome would be a novel target for cancer treatment [11]. Salinosporamide A (3), isolated from the culture of a marine actinomycete, was found to be more effective than 2 and is now undergoing clinical trials. Several proteasome inhibitors have been developed and are classified into five groups, peptide aldehydes, peptide boronates, $\beta$-lactones, epoxyketones, and macrocyclic vinyl ketones, on the basis of inhibitory mechanisms.

\section{Proteasome inhibitors: peptide aldehydes}

Peptide aldehydes ( $\odot$ Fig. 2 ), the first proteasome inhibitors [7, 12 ], are the most widely used as molecular tools for the investigation of various cellular events. Generally, peptide aldehydes act against serine and cysteine proteases. The aldehyde functional group of the inhibitor is readily attacked by a hydroxy or thiol group at the active site of the protease. In the case of the proteasome, the $\mathrm{N}$-terminal threonine residue at its active site carries

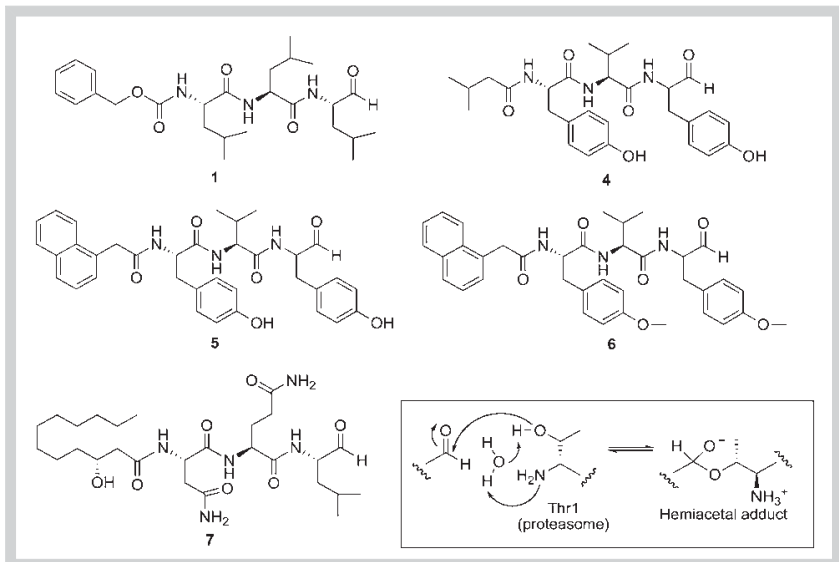

Fig. 2 Structures of proteasome inhibitors containing peptide aldehydes and their inhibitory mechanism.

out a nucleophilic attack on the aldehyde moiety of the inhibitor and then a covalent hemiacetal adduct is formed between the inhibitor and the threonine residue of the proteasome ( $\mathbf{F i g . 2}$ ). The formation of the covalent adduct is mediated by a reversible reaction under physiological conditions, and aldehyde inhibitors are rapidly oxidized into inactive acids in cells and transported out of the cell by the multidrug resistance (MDR) carrier system. Therefore, in experiments with cultured cells, effects of aldehyde inhibitors can be rapidly reversed by removal of the inhibitors. Although MG132 (1) is a potent and selective inhibitor of the chymotrypsin-like activity of the proteasome, it is not suitable for use as a therapeutic agent.

Tyropeptin A (4) was isolated from the culture broth of Kitasatospora sp. $[13,14]$ and contains an aldehyde moiety at the C-terminal. This compound inhibits the chymotrypsin-like and trypsinlike activities of the proteasome with $\mathrm{IC}_{50}$ values of 0.1 and $1.5 \mu \mathrm{g} / \mathrm{mL}$, respectively, but scarcely inhibits the caspase-like activity. In rat pheochromocytoma (PC12) cells, 4 induced neurite outgrowth, and this compound is thought to be capable of permeating cells and inhibiting intracellular proteasomal activity [15]. Momose et al. designed and synthesized several derivatives of 4 [16]. Among them, TP-104 (5) is 20-fold more potent than 4 in terms of its inhibitory effect on the chymotrypsin-like activity of the mammalian 20 S proteasome, while TP-110 (6) specifically inhibits the chymotrypsin-like but not the trypsin-like or caspase-like activity of the proteasome.

Fellutamide B (7) was originally isolated from the marine-derived Penicillium fellutanum as a cytotoxic compound [17] and found to induce the release of nerve growth factor (NGF) from fibroblasts and glial-derived cells [18]. Because of its structural similarity with 1, 7 was tested for inhibitory activity against the proteasome and found to potently inhibit the chymotrypsin-like activity with an $\mathrm{IC}_{50}$ value of $9.4 \mathrm{nM}$ along with the trypsin-like and caspase-like activities albeit less potently with $\mathrm{IC}_{50}$ values of 2.0 and $1.2 \mu \mathrm{M}$, respectively [19]. In addition, 7 increased NGF gene transcription [19]. Therefore, it can be inferred that 7 exerts neurotrophic activity through stabilization of a short-lived unidentified transcription factor that upregulates NGF gene expression. 
<smiles>CC(C)C[C@H](NC(=O)[C@H](Cc1ccccc1)NC(=O)c1cnccn1)B(O)O</smiles>

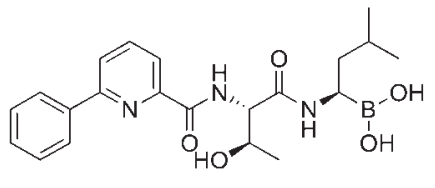

8

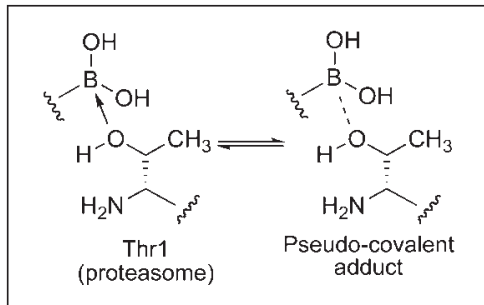

Fig. 3 Structures of proteasome inhibitors containing peptide boronates and their inhibitory mechanism. Note that bortezomib (2) and CEP-18770 (8) are under evaluation in clinical trials for cancers.

Proteasome inhibitors: peptide boronates

The development of a proteasome inhibitor suitable for therapeutic use without the defects of MG132 (1) led to the introduction of boronic acid as a functional group ( $\odot$ Fig. 3). Although boronic acid-containing inhibitors bind with the hydroxy group of the $\mathrm{N}$-terminal threonine residue in the proteasome via a noncovalent bond, their inhibitory potency and selectivity towards the proteasome are excellent in comparison with other proteasome inhibitors. Since the boron atom is able to receive the oxygen lone pair of the $\mathrm{N}$-terminal threonine residue of the proteasome, inhibitors containing boronate can form a stable tetrahedral intermediate ( $\bullet$ Fig. 3 ). Although peptide aldehydes are readily oxidized into inactive acids, boronates are not inactivated by oxidation and are not rapidly removed from the cell by the MDR system. In 2003, bortezomib (2), a synthetic boronate-containing inhibitor, was first approved by the FDA for treating relapsed multiple myelomas $[20,21]$. This inhibitor selectively inhibits the proteasome in a reversible manner and induces apoptosis of malignant cells through the inhibition of NF- $\mathrm{KB}$ signaling and stabilization of proapoptotic proteins. Clinical trials show promising results for the combination of $\mathbf{2}$ and DNA cross-linking agents in the treatment of myeloma and ovarian cancer [22]. CEP-18770 (8), a synthetic boronate derivative, is an orally active proteasome inhibitor [23], which inhibits the chymotrypsin-like activity of the proteasome at a low nanomolar concentration. This inhibitor exhibits the concentration-dependent induction of apoptotic cell death in human multiple myeloma and tumorderived cell lines, and exhibits a more favorable cytotoxicity profile toward normal human endothelial cells, bone marrow progenitors, and bone marrow-derived stromal cells than 2 [24]. Recently, it has been reported that $\mathbf{8}$ enhances the antimyeloma activity of $\mathbf{2}$ and melphalan in the xenograft models [25]. The in vitro and in vivo antitumor and anticlastogenic pharmacological profiles of $\mathbf{8}$ and its reduced cytotoxicity against a variety of normal human cell lineages compared with tumor cells provide the rationale for further studies evaluating its preclinical and clinical efficacies in multiple myeloma and other hematological malignancies. At present, $\mathbf{8}$ is undergoing phase I and II trials.

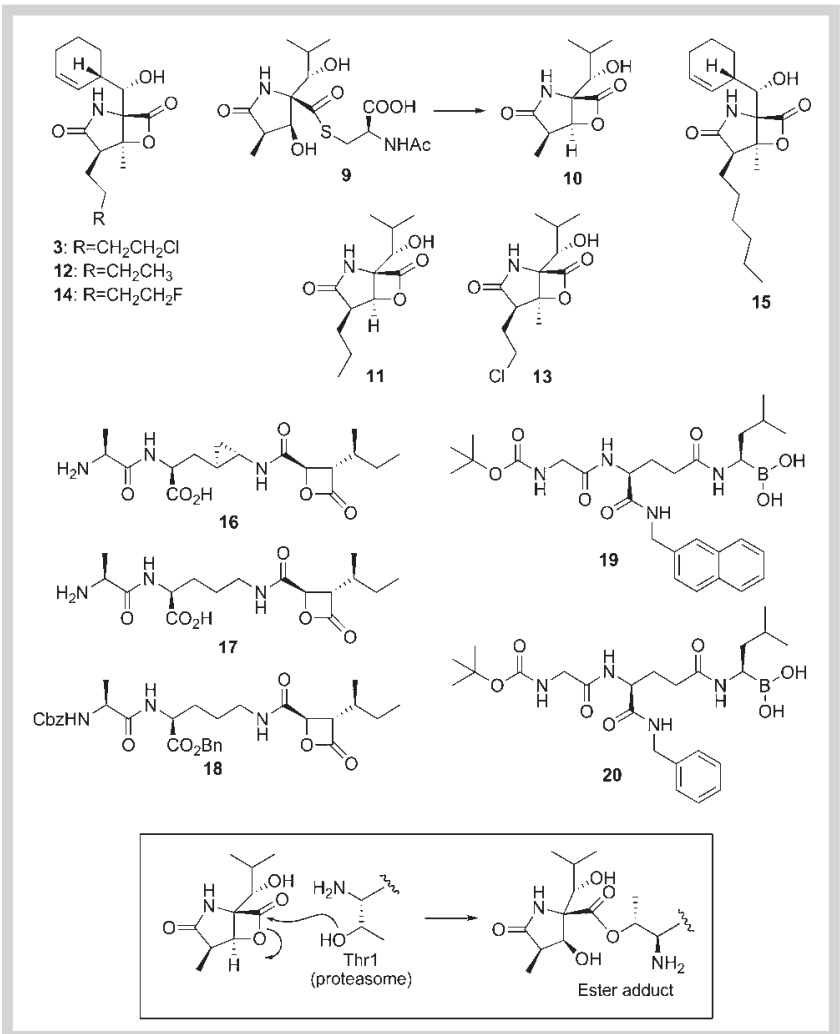

Fig. 4 Structures of proteasome inhibitors containing $\beta$-lactones and their analogs, and their inhibitory mechanism. Note that 19 and 20 lack $\beta$-lactones but contain boronates and that salinosporamide A (3) is in clinical trials for cancers.

\section{Proteasome inhibitors: $\beta$-lactones}

Lactacystin (9) ( $\odot$ Fig. 4), the first natural proteasome inhibitor, was originally isolated from the culture broth of Streptomyces sp. as an inducer of neurite outgrowth in a murine neuroblastoma cell line, Neuro-2a $[26,27]$. Subsequently, this inhibitor was found to inhibit proteasomal activity by binding with the $\mathrm{N}$-terminal threonine residue in the proteasome via a stable covalent bond ( $\bullet$ Fig. 4) [28]. The active component of 9 is clasto-lactacystin $\beta$-lactone (omuralide, 10), which is derived from 9 by elimination of the $N$-acetyl cysteine moiety to form a lactone ring [29, 30]. The cocrystallization of 9 with the proteasome revealed that the side chain residues of $\mathbf{1 0}$ are closely related to the selectivity of the inhibitor. PS-519 (11), which has an $n$-propyl group instead of the methyl group found in omuralide, is the most clinically advanced lactacystin analogue [31] and has been used in a clinical trial to treat acute stroke.

Salinosporamide A (3) was isolated from the culture of a marine bacterium of the new genus Salinispora tropica $[10,32]$ and showed strong cytotoxic activity against HCT-116 human colon carcinoma. Because of its structural similarity to $\mathbf{1 0 ,} \mathbf{3}$ was tested for inhibitory activity against the proteasome and found to inhibit the chymotrypsin-like activity 35 times more potently than $\mathbf{1 0}$. The dechloro derivative, salinosporamide B (12), is ten times less potent, suggesting that the chloro substituent in $\mathbf{3}$ is important for its inhibitory ability [33]. Several potent salinosporamide analogues have been chemically synthesized, bioengineered, and isolated from microorganisms. Antiprotealide (13), which was originally synthesized as a molecular hybrid of 3 and 10 [34], 


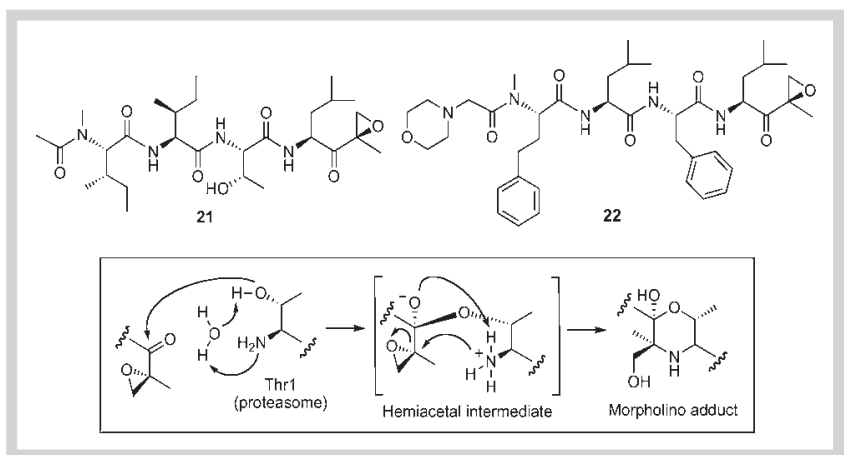

Fig. 5 Structures of proteasome inhibitors containing epoxyketones and their inhibitory mechanism. Note that carfilzomib (22) is in clinical trials for cancers.

was recently isolated from a large-scale fermentation of the bacterium [35]. Fluorosalinosporamide (14), a fluoro analogue, was biosynthesized and showed reversible binding ability toward the proteasome with an $\mathrm{IC}_{50}$ value of $1.5 \mathrm{nM}$ (the value of salinosporamide $A$ is $0.7 \mathrm{nM}$ ) [36]. Cinnabaramide $\mathrm{A}$ (15), an analogue with a structural difference in the alkyl side chain, was isolated from a terrestrial streptomycete and showed inhibition with an $\mathrm{IC}_{50}$ value of $1 \mathrm{nM}$ [37]. Although bortezomib (2) inhibits most strongly the chymotrypsin-like activity and moderately the caspase-like activity of the proteasome [38-40], 3 inhibits most strongly the chymotrypsin-like activity and moderately the trypsin-like activity of the proteasome [40]. A phase I study with 3 is currently proceeding. Although $\mathbf{2}$ is effective for the treatment of relapsed or refractory multiple myeloma, its prolonged use can be associated with toxicity and the development of drug resistance. Importantly, 3 overcomes resistance to conventional treatment and 2 [41,42]. In vivo studies using human multiple myeloma xenografts revealed that 3 shows well tolerated/prolonged survival and reduces tumor recurrence [42]. In addition, 3 was a more effective proapoptotic agent than $\mathbf{2}$ in isolated chronic lymphocytic leukemia cells [43], and the combination of $\mathbf{3}$ and a histone deacetylase inhibitor, MS-275 or valproic acid, induced greater cell death than did the combination of $\mathbf{2}$ and these inhibitors [44]. It should be noted that $\mathbf{3}$ is orally bioavailable and cytotoxic to multiple myeloma cells with reduced toxicity against normal cells compared to 2 . Furthermore, in vivo studies with a human plasmacytoma xenograft mouse model showed that a low dose combination of $\mathbf{3}$ and $\mathbf{2}$ is well tolerated and triggers synergistic inhibition of tumor growth and chymotrypsin-like, caspase-like, and trypsin-like proteasomal activities in tumor cells [45]. Combination of 3 and lenalidomide (Revlimid ${ }^{\circledR}$ ) induces synergistic anti-multiple myeloma activity in multiple myeloma cell lines or patient multiple myeloma cells [46], implying the preclinical rationale for clinical protocols evaluating lenalidomide together with 3 to improve patient outcome in multiple myeloma. The preclinical and clinical results with $\mathbf{3}$ strongly suggest that the discovery of $\mathbf{3}$ indicates the importance of metabolites from marine microorganisms for drug discovery and development [47].

Belactosins A (16) and C (17), which were isolated from a Streptomyces sp., contain the same $\beta$-lactone ring as $\mathbf{1 0}$ and inhibit the chymotrypsin-like activity of the proteasome in the same fashion as $10[48,49]$. Derivatives of 16 with more potent inhibitory effects than 16 have been synthesized [50]. Homobelactosin C
(18), a modified derivative, has an $\mathrm{IC}_{50}$ value in the low nanomolar range [51]. The structural data for the complex of the proteasome and 18 provide an explanation for the involvement of immunoproteasome subunits in the generation of antigen, and open the way for the rational design of compounds that exclusively inhibit constitutive proteasomes or immunoproteasomes [51]. Recently, analogues of $\mathbf{1 7}$ were synthesized, and their inhibitory activity was investigated [52]. Among them, its two boronate-containing peptide analogues (19 and 20) showed significant inhibition of the chymotrypsin-like activity of the 20S proteasome with $\mathrm{IC}_{50}$ values of 0.28 and $0.51 \mu \mathrm{M}$, respectively. Furthermore, the development of potent proteasome inhibitors based on a stereochemical diversity-oriented strategy with 16 and its stereo- and regioisomers is underway [53].

\section{Proteasome inhibitors: epoxyketones}

The proteasome inhibitor epoxomicin (21) († Fig.5) was originally isolated from an unidentified actinomycete strain and exhibited in vivo antitumor activity against B16 melanoma [54]. This inhibitor contains an $\alpha, \beta$-epoxyketone moiety that is involved in the formation of a morpholino adduct with the $N$-terminal threonine residue in the proteasome, which results in inactivation of the proteasome ( Fig. 5) [55]. Although clinical studies with bortezomib (2) have validated the proteasome as a therapeutic target for the treatment of multiple myeloma and some forms of non-Hodgkin's lymphoma [56], significant toxicity against normal cells has restricted the dosage. Furthermore, many patients have tumors that do not respond to $\mathbf{2}$ and others develop resistance. This has led to the need for other proteasome inhibitors with enhanced activity. Carfilzomib (PR-171, 22), which was derived from $\mathbf{2 1}$, is an irreversible proteasome inhibitor [57]. In multiple myeloma cells, 22 specifically inhibits the chymotrypsin-like activities of the proteasome and immunoproteasome [58]. In comparison to $\mathbf{2 1 ,} \mathbf{2 2}$ exhibits greater selectivity toward the chymotrypsin-like activity of the proteasome and is active against 2-resistant multiple myeloma cell lines. Since $\mathbf{2 2}$ also overcomes resistance to conventional agents and acts synergistically with dexamethasone to enhance cell death, this compound is currently under evaluation in phase I clinical trials in patients with multiple myeloma and non-Hodgkin's lymphoma. The first phase I study of $\mathbf{2 2}$ shows that the drug is well tolerated, and produces signals of activity in patients with multiple myeloma and that 22 did not produce any neuropathy [59]. These data support the further development of $\mathbf{2 2}$ in patients with hematologic malignancies.

\section{Proteasome inhibitors: macrocyclic vinyl ketones}

Syringolin A (23) ( Fig. 6) was originally isolated as a virulence factor of the plant pathogen Pseudomonas syringae pv. syringae [60] and found to induce a change in the gene expression profile similar to that in cells treated with proteasome inhibitors [61]. The crystal structure of the yeast proteasome in a complex with 23 revealed that the hydroxy group of the catalytic threonine residue exhibits a Michael type 1,4-addition to the vinyl ketone moiety in the 14-membered ring of 23 ( Fig. 6) [61]. This is a new mode of inhibition, and 23 irreversibly inhibits all three types of proteasomal activity. Recently, synthetic and structural analyses of 23 revealed critical determinants of the selectivity and potency of its inhibitory effect [62]. Furthermore, it was found that a rhodamine-tagged $\mathbf{2 3}$ selectively binds to and labels the active sites of the proteasome at therapeutic concentrations [63]. In the same fashion, glidobactin A (24), another microbial metabo- 
lite [64], inhibits the chymotrypsin- and trypsin-like activities of the proteasome and reacts with the threonine residues of the respective active sites [61]. Both $\mathbf{2 3}$ and $\mathbf{2 4}$ inhibit the proliferation and induce the apoptosis of malignant cells [61].

\section{Proteasome inhibitors: cyclic peptides}

TMC-95A (25) ( Fig. 7) was isolated from a fermentation broth of Apiospora montagnei $[65,66]$ by direct screening on the basis of inhibitory activity against the proteasome. This compound inhibits the chymotrypsin-like, trypsin-like, and caspase-like activities of the proteasome with $\mathrm{IC}_{50}$ values of $5.4,200$, and $60 \mathrm{nM}$, respectively. The cocrystallization of $\mathbf{2 5}$ with the yeast proteasome revealed that $\mathbf{2 5}$ is bound to the core particle of the proteasome through specific hydrogen bonds and specifically blocks the proteasomal active sites non-covalently $[67,68]$. In addition, 25 was found to induce neurite outgrowth in rat PC12 cells [69]. Argyrin A (26) was originally isolated from the myxobacterium Archangium gephyra as an immunosuppressive cyclic peptide [70] and identified as a small molecule capable of promoting the accumulation of p27kip1, a cyclin-dependent kinase inhibitor, in cancer cells by a high-throughput whole-cell assay [71]. It should be noted that the level of $\mathrm{p} 27^{\mathrm{kip} 1}$, a tumor suppressor protein and a proteasome substrate, is often reduced in human cancer cells and that the expression of a degradation-resistant $\mathrm{p} 27^{\mathrm{kip} 1}$ mutant reduced the number of intestinal adenomatous polyps that developed into invasive carcinomas. It was found that $\mathbf{2 6}$ inhibits most strongly the chymotrypsin-like activity, moderately the caspase-like activity, and weakly the trypsin-like activity of the proteasome [71].

\section{Other proteasome inhibitors}

Various proteasome inhibitors isolated from natural sources are shown in 0 Fig. 8. Gliotoxin (27) is a fungal epipolythiodioxopiperazine toxin and contains a heterobicyclic structure with a disulfide bridge. This compound was originally identified as a potent inhibitor of NF-KB activation in T and B cells [72]. Additional studies showed that $\mathbf{2 7}$ inhibits the chymotrypsin-like activity of the proteasome and that the disulfide bridge is responsible for the inhibition [73].

We performed a screening of marine organisms and marine-derived fungi based on the inhibition of the chymotrypsin-like activity of the proteasome and isolated agosterol derivatives [e.g., agosterol C (28)], polyhydroxysterols, from a marine sponge, Acanthodendrilla sp., as proteasome inhibitors [74]. Agosterols were originally isolated from the marine sponge Spongia sp. and found to reverse multidrug resistance in tumor cells $[75,76]$. Among the agosterol derivatives, $\mathbf{2 8}$ most strongly inhibited the chymotrypsin-like activity of the proteasome with an $\mathrm{IC}_{50}$ value of $10 \mu \mathrm{g} / \mathrm{mL}$. Interestingly, they differ in their inhibitory potency despite their structural similarity. We also isolated another proteasome inhibitor, secomycalolide A (29), together with known compounds, mycalolide A (30) and 30-hydroxymycalolide A (31), from a marine sponge of the genus Mycale [77]. Among the mycalolides, 29 has the most potent effect on the chymotrypsinlike activity of the proteasome with an $\mathrm{IC}_{50}$ value of $11 \mu \mathrm{g} / \mathrm{mL}$. Extensive searches for proteasome inhibitors in plants and foods have been performed. Activity-guided fractionation of a chloroform-soluble extract of the leaves of Ormosia sumatrana led to the isolation of a new cerebroside, sumatranoside (32), as a proteasome inhibitor with an $\mathrm{IC}_{50}$ value of $30 \mu \mathrm{M}$ [78]. Curcumin (33), the major active ingredient of turmeric (Curcuma longa) used in South Asian cuisine for centuries, markedly inhibited the

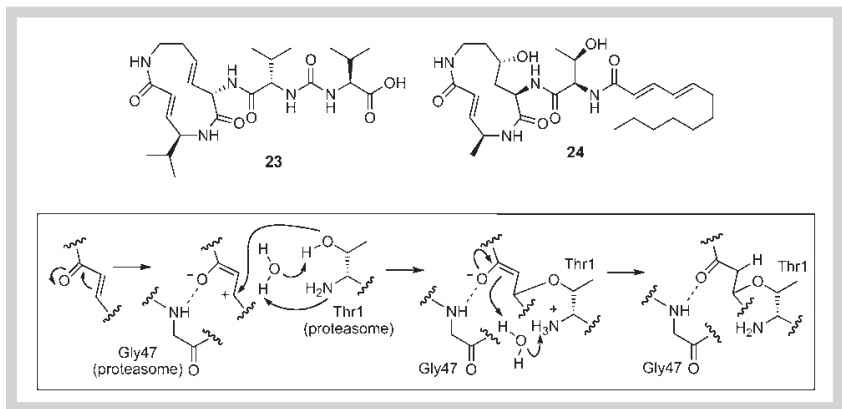

Fig. 6 Structures of proteasome inhibitors containing macrocyclic vinyl ketones and their inhibitory mechanism.
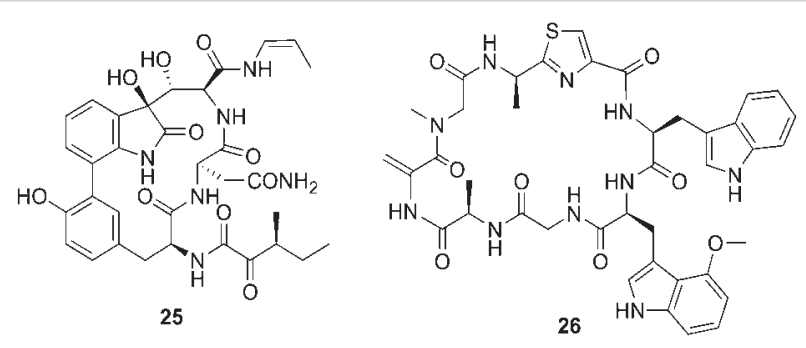

Fig. 7 Structures of cyclic peptides as proteasome inhibitors.

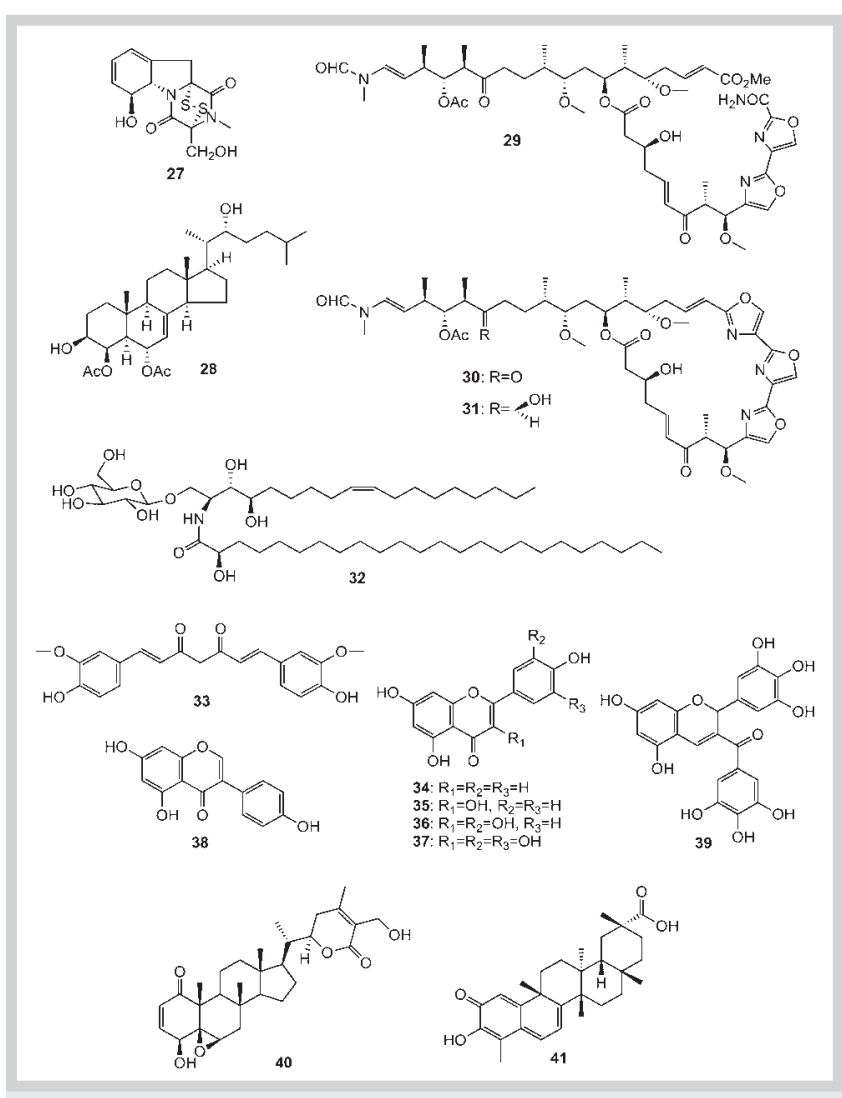

Fig. 8 Structures of proteasome inhibitors other than six groups shown in - Figs. 2-7. 
chymotrypsin-like activity of a purified rabbit $20 \mathrm{~S}$ proteasome with an $\mathrm{IC}_{50}$ value of $1.85 \mu \mathrm{M}$ and also inhibited the cellular $26 \mathrm{~S}$ proteasome [79]. Four dietary flavonoids, apigenin (34), kaempferol (35), quercetin (36), and myricetin (37), inhibited the chymotrypsin-like activity of the $26 \mathrm{~S}$ proteasome in intact Jurkat $\mathrm{T}$ cells with $\mathrm{IC}_{50}$ values of $1,11,2$, and $12 \mu \mathrm{M}$, respectively [80]. Genistein (38), a soy isoflavone [81], (-)-epi-gallocatechin gallate (EGCG) (39), a green tea polyphenol [82], withaferin A (40), a steroidal lactone from the medicinal plant "Indian Winter Cherry" (Withania somnifera) [83], and celastrol (41), a triterpene from the Chinese "Thunder of God Vine" (Tripterygium wilfordii) [84], also inhibited the chymotrypsin-like activity of a purified $20 \mathrm{~S}$ proteasome with $\mathrm{IC}_{50}$ values of $26,0.30,4.5$, and $2.5 \mu \mathrm{M}$, respectively.

\section{Targeting the Ubiquitin System}

$\nabla$

The ubiquitin-proteasome pathway consists of the ubiquitin system and the protein degradation system (the $26 \mathrm{~S}$ proteasome) (see Fig. 1). The former contains the ubiquitin-activating enzyme (E1), ubiquitin-conjugating enzyme (E2) and ubiquitin ligase (E3), and catalyzes the ubiquitination of client proteins. In addition to inhibitors targeting the proteasome, various inhibitors of the ubiquitin system consisting of E1, E2 and E3 enzymes have been developed.

\section{Ubiquitin ligase (E3) inhibitors}

Among enzymes in the ubiquitin system, E3s are a large family that recognize huge numbers of client proteins and target them for degradation $[85,86]$. They are classified into three major groups, the RING, HECT, and U-box families, on the basis of their domain structures and substrate recognition mechanisms. As E3 definitively determines which client proteins are ubiquitinated, a specific inhibitor against an E3 recognizing a key client protein could be a good lead for the treatment of diseases associated with degradation of the key client protein. Among many E3s, MDM2 (mouse double minute 2) or HDM2 (human double minute 2), a RING-type E3 for p53 protein, is frequently used as a target for inhibitor development [87]. Although HDM2 is normally expressed at a low level, it is overexpressed in a variety of human cancers. On the other hand, p53, a tumor suppressor, induces growth arrest and apoptosis upon activation by various stimuli such as DNA damage [88]. The crystal structure of the 109-residue amino-terminal domain of MDM2, which binds to a 15-residue transactivation domain peptide of $\mathrm{p} 53$, revealed that MDM2 has a deep hydrophobic cleft, to which the p53 peptide binds [89]. Therefore, targeting MDM2/HDM2 is a promising way to reactivate $\mathrm{p} 53$, inducing apoptosis in human cancer cells. For example, nutlin-3 (42) ( Fig. 9) was discovered by screening a chemical library as an MDM2 antagonist and found to suppress tumor progression in nude mice bearing subcutaneous human cancer xenografts [89]. The development of $\mathbf{4 2}$ strongly indicates that MDM2 antagonists would be promising candidates for leads in the treatment of cancer. Recently, it has been reported that the combination of $\mathbf{4 2}$ with bortezomib (2) mediates additive cytotoxicity against 2 -sensitive multuple myeloma cell lines and synergistic activity against epithelial carcinoma cell lines and that non-genotoxic activation of the p53 pathway using $\mathbf{4 2}$ can sensitize epithelial carcinoma cells to $\mathbf{2}$ in a manner that is not suppressed by microenvironmental interactions, i.e., even in the presence of stromal cells [90].

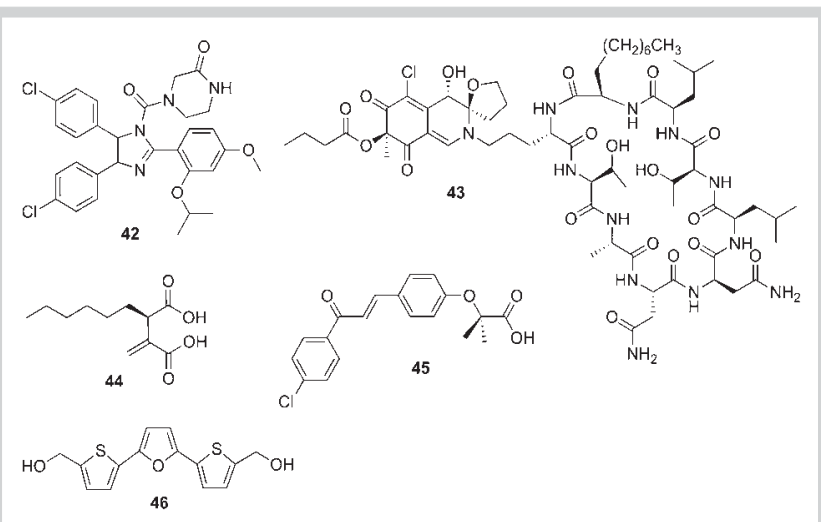

Fig. 9 Structures of ubiquitin ligase (E3) inhibitors.

Chlorofusin (43), the first MDM2 antagonist from natural sources, was isolated from the culture of a Fusarium sp. with an $\mathrm{IC}_{50}$ value of $4.6 \mu \mathrm{M}$ [91]. The absolute configuration of chlorofusin was determined by total synthesis [92,93]. Furthermore, inhibition of MDM2-p53 binding was evaluated with seven chromophore diastereomers of $\mathbf{4 3}$ [94]. The biosynthesis of $\mathbf{4 3}$ was also investigated [95].

By bioassay-guided isolation, (-)-hexylitaconic acid (44) was isolated from a culture of marine-derived fungus as an inhibitor of p53-HDM2 interaction [96]. Since 44 is unable to inhibit the interaction of p53 with COP1, another E3 of the HECT-type for p53, it can be inferred that $\mathbf{4 4}$ binds to HDM2 protein. Recently, the stereogenic center of $\mathbf{4 4}$ was determined to be $R$ by vibrational circular dichroism (VCD) spectroscopy [97]. Its synthetic $S$ (+)-enatiomer also had an inhibitory effect on the p53-HDM2 interaction, which was comparable to that of the natural $R$-(-)-enatiomer (44) [97].

The interaction of chalcones [e.g., chalcone C (45)] with the p53MDM2 system was analyzed by NMR spectroscopy $\left({ }^{1} \mathrm{H}-{ }^{15} \mathrm{~N}\right.$ HSQC spectrum) [98], since chalcone derivatives were reported to inhibit tumorigenesis [99]. Chalcones were found to bind to a subsite of the p53-binding cleft of MDM2. On the other hand, RITA (46) was discovered by screening a chemical library as an inhibitor of p53-MDM2 interaction through its binding to p53 protein [100].

\section{Ubiquitin-activating enzyme (E1) inhibitors}

Ubiquitin is first activated by the ubiquitin-activating enzyme (E1) in the ubiquitin-proteasome system (๑ Fig. 1). In the E1mediated ubiquitin-activation process, ubiquitin and ATP bind to different sites in the E1 enzyme, and E1 catalyzes the formation of a ubiquitin-adenylate intermediate from ubiquitin and ATP, and subsequently the binding of ubiquitin to a cysteine residue at the E1 active site via a thiol ester linkage. Then, the highenergy intermediate of ubiquitin is transferred to the thiol group of the active cysteine residue in the ubiquitin-conjugating enzyme (E2) and then to the client proteins, mediated by ubiquitin ligase (E3) [1,5]. Since E1 activity is thought to be essential for the ubiquitin-proteasome system, developing inhibitors against E1 is another possible route of drug development for the treatment of cancer.

Two natural E1 inhibitors, panepophenanthrin (47) (๑ Fig. 10) [101] and himeic acid A (48) [102], have been isolated from microorganisms. As the first natural E1 inhibitor, $\mathbf{4 7}$ was isolated 


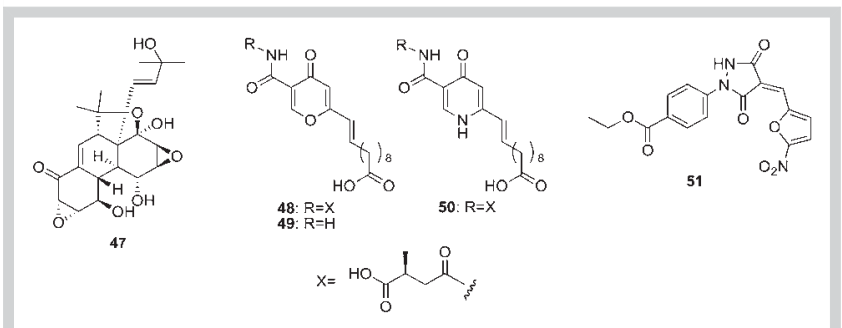

Fig. 10 Structures of ubiquitin-activating enzyme (E1) inhibitors.

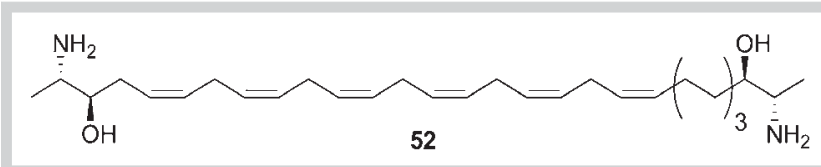

Fig. 11 Structure of a ubiquitin-conjugating enzyme (E2) inhibitor.

In summary, targeting of the E1, E2, and E3 enzymes in the ubiquitin system offers promising prospects for drug discovery.

\section{Targeting the Delivery System Connecting the Ubiquitin System to the Proteasome $\nabla$}

As described above, the ubiquitin-proteasome system consists of two subsystems, the ubiquitin system and the protein degradation system (the 26S proteasome). Recently, a third system, the so-called delivery system, was proposed to function in the delivery of ubiquitinated proteins to the $26 \mathrm{~S}$ proteasome (see 0 Fig. 1 ). The proteasome subunit Rpn10 functions as an intrinsic ubiquitin receptor of the proteasome [113] and Rpn13 was recently found to be an additional intrinsic ubiquitin receptor [114,115]. The delivery system consisting of intrinsic ubiquitin receptors Rpn10/Rpn13 and extrinsic ubiquitin receptors such as Rad23 and Dsk2 functions as the third system in the ubiquitin-proteasome pathway, although the mechanism for the discrimination of ubiquitinated client proteins by the respective ubiquitin receptors remains unclear $[116,117]$. Therefore, specific rather than general targeting of the respective ubiquitin receptors could be an effective approach in the treatment of specific client proteinassociated diseases.

Girolline (53) (๑ Fig. 12) was originally isolated as an antitumor compound from a marine sponge, but a phase I clinical study with this compound showed severe side effects in patients and no apparent antitumor activity [118]. We found that 53 induces G2/M cell cycle arrest in several tumor cell lines. In addition, ubiquitinated p53 but no other protein accumulated in cells treated with 53, but this compound does not inhibit proteasomal activity [119]. Although the exact target of $\mathbf{5 3}$ has not been identified, it was proposed that this compound inhibits the delivery of ubiquitinated p53 protein to the proteasome.

Ubistatin (54) was discovered by searching a chemical library for an inhibitor of destruction box-dependent protein degradation [120]. It was found that 54 binds to the ubiquitin chain of ubiquitinated proteins and inhibits ubiquitin-dependent proteolysis. Thus, compounds inhibiting the delivery system for ubiquitinated proteins could serve as novel inhibitors targeting the ubiquitin-proteasome system.

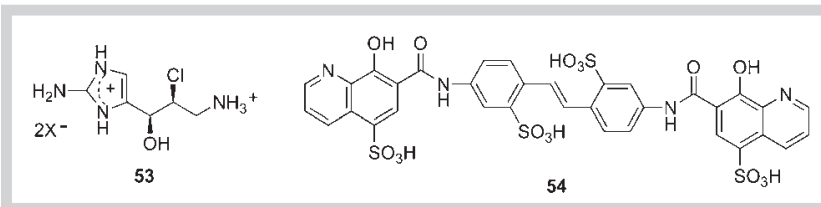

Fig. 12 Structures of inhibitors targeting the delivery system connecting the ubiquitin system to the 265 proteasome. 


\section{Targeting Deubiquitinating Enzymes}

In the polyubiquitin chain, the $C$-terminal carboxyl group of one ubiquitin monomer is covalently linked with the $\varepsilon$-amino group of the lysine residue in another ubiquitin monomer or the client protein via an isopeptide bond. Upon degradation of the polyubiquitinated client protein by the proteasome, the polyubiquitin chain is recognized by intrinsic ubiquitin receptors of the $26 \mathrm{~S}$ proteasome as well as extrinsic ubiquitin receptors in the third system and is converted to ubiquitin monomers by the actions of intrinsic and extrinsic deubiquitinating enzymes (DUBs) [121]. Thus, it is now known that deubiquitination mediated by the actions of various DUBs plays important regulatory roles in various cellular events [122].

Prostaglandins (PGs) function as intracellular signal mediators in the regulation of a variety of physiological processes, including inflammation and immune responses. J series PGs [e.g., $\Delta_{12}-\mathrm{PGJ}_{2}$ (55)] ( $\odot$ Fig. 13) with a unique exocyclic $\alpha, \beta$-unsaturated ketone inhibit ubiquitin isopeptidase activity in the proteasome-mediated proteolytic pathway, while $\mathrm{PGA}_{1}, \mathrm{PGB}_{1}, \mathrm{PGE}_{2}$, and 15-keto$\mathrm{PGE}_{2}$ are inactive [123]. The former J series PGs cause apoptosis, independently of p53-mediated gene transactivation. Punaglandins [e.g., punaglandin 4 (56)] isolated from the soft coral Telesto riisei are highly functional cyclopentadienone and cyclopentenone prostaglandins chlorinated at the endocyclic $\alpha$-carbon position, and inhibit ubiquitin isopeptidase activity and exhibit antiproliferative effects more potently than J series PGs [124]. Recently, a small-molecule inhibitor (HBX 41,108, a cyano-indenopyrazine derivative, 57) of USP7/HAUSP, a member of the ubiquitin-specific protease (USP) family of DUBs, was isolated by highthroughput screening [125]. It was found that the treatment of cancer cells with 57 results in the accumulation of p53 and that 57 inhibits cancer cell growth and induces apoptosis. This suggests that compounds inhibiting specific DUBs could act as novel anticancer drugs. Although drug discovery targeting DUBs is in its early stages, a better understanding of the DUBs with regard to their mechanisms of action and substrate recognition may enable the development of small-molecule inhibitors for effective anticancer treatment.

\section{Future Perspectives}

$\nabla$

The ubiquitin-proteasome system controls a wide range of cellular events including cell cycle progression, and defects associated with this system result in various diseases including cancer and neurodegenerative disorders. Thus, the ubiquitin-proteasome system is emerging as a significant target in anticancer therapies. Bortezomib (2), a synthetic proteasome inhibitor, is already on the market for the treatment of patients with multiple myeloma and is also undergoing clinical trials for other cancers. In preclinical studies, $\mathbf{2}$ showed antitumor activity against a variety of solid tumors, including breast, gastric, colon, pancreas, and non-small lung cancers [126]. In addition, several natural and synthetic inhibitors targeting the proteasome, salinosporamide A (3), CEP18770 (8), and carfilzomib (22), are also in clinical trials for cancers. Inhibitors targeting the ubiquitin system, the delivery system, and deubiquitinating enzymes are also candidates for anticancer drugs and several compounds are now undergoing preclinical and clinical trials for cancers. In 2004, Ciechanover, Hershko, and Rose received the Nobel Prize in Chemistry for the discovery of ubiquitin-mediated protein degradation. Although

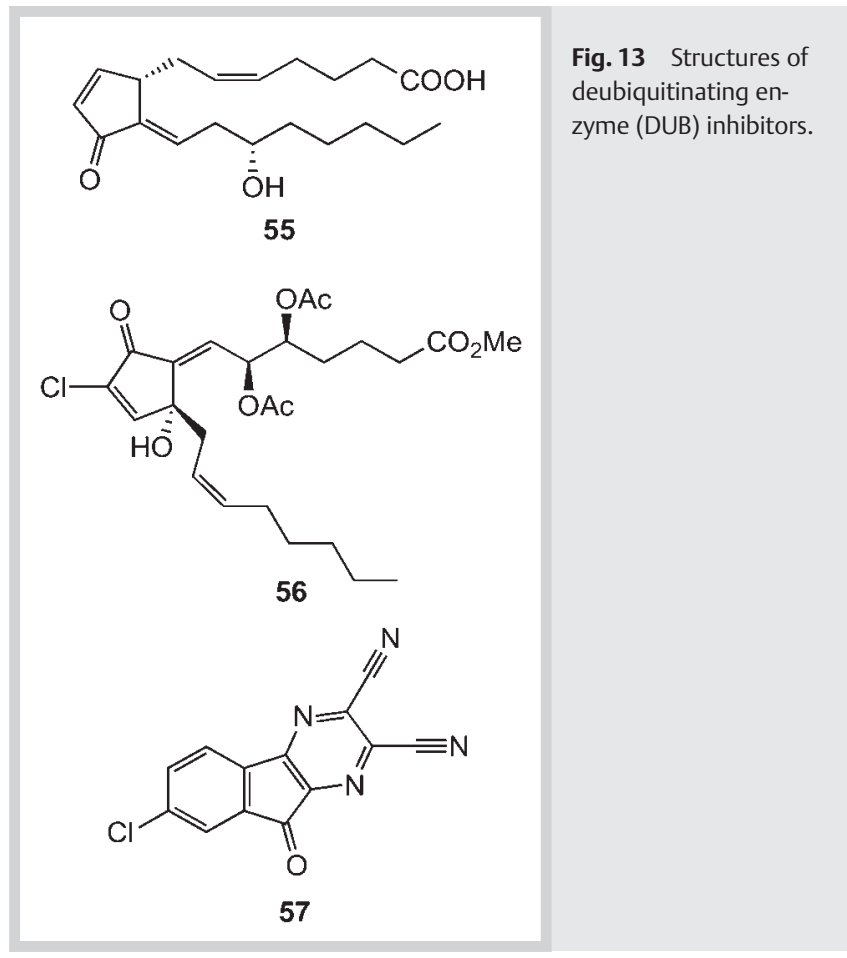

the mechanisms and functions of the ubiquitin-proteasome system have been investigated extensively, a comprehensive understanding of the complex ubiquitin-proteasome system as well as the development of inhibitors of this system by searching natural sources and chemical libraries and also by chemical synthesis is needed to develop efficient anticancer drugs in the future.

\section{References}

1 Hershko A, Ciechanover A. The ubiquitin system. Annu Rev Biochem 1998; 67: 425-479

2 Glickman MH, Ciechanover A. The ubiquitin-proteasome proteolytic pathway: destruction for the sake of construction. Physiol Rev 2002; 82: $373-428$

3 Tai HC, Schuman EM. Ubiquitin, the proteasome and protein degradation in neuronal function and dysfunction. Nat Rev Neurosci 2008; 9: 826-838

4 Voges D, Zwickl P, Baumeister W. The 26S proteasome: a molecular machine designed for controlled proteolysis. Annu Rev Biochem 1999; 68: 1015-1068

5 Pickart CM. Mechanisms underlying ubiquitination. Annu Rev Biochem 2001; 70: 503-533

6 DeMartino GN, Gillette TG. Proteasomes: mechanisms for all reasons. Cell 2007; 128: 659-662

7 Rock KL, Gramm C, Rothstein L, Clark K, Stein R, Dick L, Hwang D, Goldberg $A L$. Inhibitors of the proteasome block the degradation of most cell proteins and the generation of peptides presented on MHC class I molecules. Cell 1994; 78: 761-771

8 Adams J. Potential for proteasome inhibition in the treatment of cancer. Drug Discov Today 2003; 8: 307-315

9 Adams J, Behnke M, Chen S, Cruickshank AA, Dick LR, Grenier L, Klunder JM, Ma YT, Plamondon L, Stein RL. Potent and selective inhibitors of the proteasome: dipeptidyl boronic acids. Bioorg Med Chem Lett 1998; 8: 333-338

10 Feling RH, Buchanan GO, Mincer TJ, Kauffman CA, Jensen PR, Fenical W. Salinosporamide A: a highly cytotoxic proteasome inhibitor from a novel microbial source, a marine bacterium of the new genus Salinospora. Angew Chem Int Ed 2003; 42: 355-357

11 Sánchez-Serrano I. Success in translational research: lessons from the development of bortezomib. Nat Rev Drug Discov 2006; 5: 107-114

12 Vinitsky A, Michaud C, Powers JC, Orlowski M. Inhibition of the chymotrypsin-like activity of the pituitary multicatalytic proteinase complex. Biochemistry 1992; 31: 9421-9428 
13 Momose I, Sekizawa R, Hashizume H, Kinoshita N, Honma Y, Hamada M, Iinuma $\mathrm{H}$, Takeuchi $T$. Tyropeptins A and B, new proteasome inhibitors produced by Kitasatospora sp. MK993-dF2. I. Taxonomy, isolation, physico-chemical properties and biological activities. J Antibiot 2001; 54: 997-1003

14 Momose I, Sekizawa R, Hirosawa S, Ikeda D, Naganawa H, Iinuma $H$, Takeuchi T. Tyropeptins A and B, new proteasome inhibitors produced by Kitasatospora sp. MK993-dF2. II. Structure determination and synthesis. J Antibiot 2001; 54: 1004-1012

15 Momose I, Sekizawa R, Iinuma H, Takeuchi T. Inhibition of proteasome activity by tyropeptin A in PC12 cells. Biosci Biotechnol Biochem 2002; 66: 2256-2258

16 Momose I, Umezawa Y, Hirosawa S, Iinuma H, Ikeda D. Structure-based design of derivatives of tyropeptin $A$ as the potent and selective inhibitors of mammalian 20S proteasome. Bioorg Med Chem Lett 2005; 15 : 1867-1871

17 Shigemori H, Wakuri S, Yazawa K, Nakamura T, Sasaki T, Kobayashi J. Fellutamides A and B, cytotoxic peptides from a marine fish-possessing fungus Penicillium fellutanum. Tetrahedron 1991; 47: 8529-8534

18 Yamaguchi K, Tsuji T, Wakuri S, Yazawa K, Kondo K, Shigemori H, Kobayashi J. Stimulation of nerve growth factor synthesis and secretion by fellutamide A in vitro. Biosci Biotechnol Biochem 1993; 57: 195-199

19 Hines J, Groll M, Fahnestock M, Crews CM. Proteasome inhibition by fellutamide B induces nerve growth factor synthesis. Chem Biol 2008; 15 : 501-512

20 Kane RC, Bross PF, Farrell AT, Pazdur R. Velcade: U.S. FDA approval for the treatment of multiple myeloma progressing on prior therapy. Oncologist 2003; 8: 508-513

21 Bross PF, Kane RC, Farrell AT, Abraham S, Benson K, Brower ME, Bradley S, Gobburu JV, Goheer A, Lee SL, Leighton J, Liang CY, Lostritto RT, McGuinn WD, Morse DE, Rahman A, Rosario LA, Verbois SL, Williams G, Wang YC, Pazdur R. Approval summary for bortezomib for injection in the treatment of multiple myeloma. Clin Cancer Res 2004; 10: 3954-3964

22 Mitsiades N, Mitsiades CS, Richardson PG, Poulaki V. The proteasome inhibitor PS-341 potentiates sensitivity of multiple myeloma cells to conventional chemotherapeutic agents: therapeutic applications. Blood 2003; 101: 2377-2380

23 Dorsey BD, Iqbal M, Chatterjee S, Menta E, Bernardini R, Bernareggi A, Cassarà PG, D'Arasmo G, Ferretti E, De Munari S, Oliva A, Pezzoni G, Allievi C, Strepponi I, Ruggeri B, Ator MA, Williams M, Mallamo JP. Discovery of a potent, selective, and orally active proteasome inhibitor for the treatment of cancer. J Med Chem 2008; 51: 1068-1072

24 Piva R, Ruggeri B, Williams M, Costa G, Tamagno I, Ferrero D, Giai V, Coscia M, Peola S, Massaia M, Pezzoni G, Allievi C, Pescalli N, Cassin M, di Giovine S, Nicoli P, de Feudis P, Strepponi I, Roato I, Ferracini R, Bussolati B, Camussi G, Jones-Bolin S, Hunter K, Zhao H, Neri A, Palumbo A, Berkers C, Ovaa H, Bernareggi A, Inghirami G. CEP-18770: a novel, orally active proteasome inhibitor with a tumor-selective pharmacologic profile competitive with bortezomib. Blood 2008; 111: 2765-2775

25 Sanchez E, Li M, Steinberg JA, Wang C, Shen J, Bonavida B, Li ZW, Chen H, Berenson JR. The proteasome inhibitor CEP-18770 enhances the antimyeloma activity of bortezomib and melphalan. Br J Haematol 2009; 148: $569-581$

26 Ōmura S, Fujimoto T, Otoguro K, Matsuzaki K, Moriguchi R, Tanaka H, Sasaki Y. Lactacystin, a novel microbial metabolite, induces neuritogenesis of neuroblastoma cells. J Antibiot 1991; 44: 113-116

27 Ōmura S, Matsuzaki K, Fujimoto T, Kosuge K, Furuya T, Fujita S, Nakagawa A. Structure of lactacystin, a new microbial metabolite which induces differentiation of neuroblastoma cells. J Antibiot 1991; 44: 117118

28 Fenteany G, Standaert RF, Reichard GA, Corey EJ, Schreiber SL. A B-lactone related to lactacystin induces neurite outgrowth in a neuroblastoma cell line and inhibits cell cycle progression in an osteosarcoma cell line. Proc Natl Acad Sci USA 1994; 91: 3358-3362

29 Dick LR, Cruikshank AA, Grenier L, Melandri FD, Nunes SL, Stein RL. Mechanistic studies on the inactivation of the proteasome by lactacystin: a central role for clasto-lactacystin $\beta$-lactone. J Biol Chem 1996; 271: 7273-7276

30 Fenteany G, Standaert RF, Lane WS, Choi S, Corey EJ, Schreiber SL. Inhibition of proteasome activities and subunit-specific amino-terminal threonine modification by lactacystin. Science 1995; 268: 726-731

31 Elliott PJ, Zollner TM, Boehncke WH. Proteasome inhibition: a new antiinflammatory strategy. J Mol Med 2003; 115: 235-245

32 Macherla VR, Mitchell SS, Manam RR, Reed KA, Chao TH, Nicholson B, Deyanat-Yazdi G, Mai B, Jensen PR, Fenical WF, Neuteboom STC, Lam KS,
Palladino MA, Potts BCM. Structure-activity relationship studies of salinosporamide $\mathrm{A}$ (NPI-0052), a novel marine derived proteasome inhibitor. J Med Chem 2005; 48: 3684-3687

33 Williams PG, Buchanan GO, Feling RH, Kauffman CA, Jensen PR, Fenical $W$. New cytotoxic salinosporamides from the marine actinomycete Salinispora tropica. J Org Chem 2005; 70: 6196-6203

34 Reddy LR, Fournier JF, Reddy BVS, Corey EJ. An efficient, stereocontrolled synthesis of a potent omuralide-salinosporin hybrid for selective proteasome inhibition. J Am Chem Soc 2005; 127: 8974-8976

35 Manam RR, Macherla VR, Tsueng G, Dring CW, Weiss J, Neuteboom STC, Lam KC, Potts BC. Antiprotealide is a natural product. J Nat Prod 2009; 72: 295-297

36 Eustáquio AS, Moore BS. Mutasynthesis of fluorosalinosporamide, a potent and reversible inhibitor of the proteasome. Angew Chem Int Ed 2008; 47: 3936-3938

37 Stadler M, Bitzer J, Mayer-Bartschmid A, Müller H, Benet-Buchholz J, Gantner F, Tichy HV, Reinemer P, Bacon KB. Cinnabaramides A-G: analogues of lactacystin and salinosporamide from a terrestrial streptomycete. J Nat Prod 2007; 70: 246-252

38 Groll M, Berkers CR, Ploegh HL, Ovaa H. Crystal structure of the boronic acid-based proteasome inhibitor bortezomib in complex with the yeast 20 S proteasome. Cancer Cell 2006; 14: 451-456

39 Berkers CR, Verdoes M, Lichtman E, Fiebiger E, Kessler BM, Anderson KC, Ploegh $\mathrm{HL}$, Ovaa $\mathrm{H}$, Galardy PJ. Activity probe for in vivo profiling of the specificity of proteasome inhibitor bortezomib. Nat Methods 2005; 2: 357-362

40 Chauhan D, Catley L, Li G, Podar K, Hideshima T, Velankar M, Mitsiades C, Mitsiades N, Yasui H, Letai A, Ovaa H, Berkers C, Nicholson B, Chao TH, Neuteboom ST, Richardson P, Palladino MA, Anderson KC. A novel orally active proteasome inhibitor induces apoptosis in multiple myeloma cells with mechanisms distinct from bortezomib. Cancer Cell 2005; 8: 407-419

41 Anderson KC. Targeted therapy of multiple myeloma based upon tumor-microenvironmental interactions. Exp Hematol 2007; 35: 155162

42 Chauhan D, Hideshima T, Anderson KC. A novel proteasome inhibitor NPI-0052 as an anticancer therapy. Br J Cancer 2006; 95: 961-965

43 Ruiz S, Krupnik Y, Keating M, Chandra J, Palladino M, McConkey D. The proteasome inhibitor NPI-0052 is a more effective inducer of apoptosis than bortezomib in lymphocytes from patients with chronic lymphocytic leukemia. Mol Cancer Ther 2006; 5: 1836-1843

44 Miller CP, Ban K, Dujka ME, McConkey DJ, Munsell M, Palladino M, Chandra J. NPI-0052, a novel proteasome inhibitor, induces caspase-8 and ROS-dependent apoptosis alone and in combination with HDAC inhibitors in leukemia cells. Blood 2007; 110: 267-277

45 Chauhan D, Singh A, Brahmandam M, Podar K, Hideshima T, Richardson P, Munshi N, Palladino MA, Anderson KC. Combination of proteasome inhibitors bortezomib and NPI-0052 trigger in vivo synergistic cytotoxicity in multiple myeloma. Blood 2008; 111: 1654-1664

46 Chauhan D, Singh AV, Ciccarelli B, Richardson PG, Palladino MA, Anderson KC. Combination of novel proteasome inhibitor NPI-0052 and lenalidomide trigger in vitro and in vivo synergistic cytotoxicity in multiple myeloma. Blood 2010; 115: 834-845

47 Fenical W, Jensen PR, Palladino MA, Lam KS, Lloyd GK, Potts BC. Discovery and development of the anticancer agent salinosporamide A (NPI0052). Bioorg Med Chem 2009; 17: 2175-2180

48 Asai A, Hasegawa A, Ochiai K, Yamashita Y, Mizukami T. Belactosin A, a novel antitumor antibiotic acting on cyclin/CDK mediated cell cycle regulation, produced by Streptomyces sp. J Antibiot 2000; 53: 81-83

49 Asai A, Tsujita T, Sharma SV, Yamashita Y, Akinaga S, Funakoshi M, Kobayashi H, Mizukami T. A new structural class of proteasome inhibitors identified by microbial screening using yeast-based assay. Biochem Pharmacol 2004; 67: 227-234

50 Yoshida K, Yamaguchi K, Sone T, Unno Y, Asai A, Yokosawa H, Matsuda A Arisawa M, Shuto S. Synthesis of 2,3- and 3,4-methanoamino acid equivalents with stereochemical diversity and their conversion into the tripeptide proteasome inhibitor belactosin A and its highly potent cis-cyclopropane stereoisomer. Org Lett 2008; 10: 3571-3574

51 Groll M, Larionov OV, Huber R, de Meijere A. Inhibitor-binding mode of homobelactosin C to proteasomes: new insights into class I MHC ligand generation. Proc Natl Acad Sci USA 2006; 103: 4576-4579

52 Nakamura H, Watanabe M, Ban HS, Nabeyama W, Asai A. Synthesis and biological evaluation of boron peptide analogues of belactosin $C$ as proteasome inhibitors. Bioorg Med Chem Lett 2009; 19: 3220-3224 
53 Yoshida K, Yamaguchi K, Mizuno A, Unno Y, Asai A, Sone T, Yokosawa $H$, Matsuda A, Arisawa M, Shuto S. Three-dimensional structure-activity relationship study of belactosin A and its stereo- and regioisomers: development of potent proteasome inhibitors by a stereochemical diversity-oriented strategy. Org Biomol Chem 2009; 7: 1868-1877

54 Hanada M, Sugawara K, Kaneta K, Toda S, Nishiyama Y, Tomita K, Yamamoto H, Konishi M, Oki T. Epoxomicin, a new antitumor agent of microbial origin. J Antibiot 1992; 45: 1746-1752

55 Groll M, Kim KB, Kairies N, Huber R, Crews CM. Crystal structure of epoxomicin: 20S proteasome reveals a molecular basis for selectivity of $\alpha^{\prime}, \beta^{\prime}$-epoxyketone proteasome inhibitors. J Am Chem Soc 2000; 122: $1237-1238$

56 Goy A, Younes A, McLaughlin P, Pro B, Romaguera JE, Hagemeister F, Fayad L, Dang NH, Samaniego F, Wang M, Broglio K, Samuels B, Gilles $F$, Sarris AH, Hart S, Trehu E, Schenkein D, Cabanillas F, Rodriguez AM. Phase II study of proteasome inhibitor bortezomib in relapsed or refractory B-cell non-Hodgkin's lymphoma. J Clin Oncol 2005; 23: 667675

57 Kuhn DJ, Chen Q Voorhees PM, Strader JS, Shenk KD, Sun CM, Demo SD, Bennett MK, van Leeuwen FW, Chanan-Khan AA, Orlowski RZ. Potent activity of carfilzomib, a novel, irreversible inhibitor of the ubiquitin-proteasome pathway, against preclinical models of multiple myeloma. Blood 2007; 110: 3281-3290

58 Parlati F, Lee SJ, Aujay M, Suzuki E, Levitsky K, Lorens JB, Micklem DR, Ruurs P, Sylvain C, Lu Y, Shenk KD, Bennett MK. Carfilzomib can induce tumor cell death through selective inhibition of the chymotrypsin-like activity of the proteasome. Blood 2009; 114: 3439-3447

59 O'Connor OA, Stewart AK, Vallone M, Molineaux CJ, Kunkel LA, Gerecitano JF, Orlowski RZ. A phase 1 dose escalation study of the safety and pharmacokinetics of the novel proteasome inhibitor carfilzomib (PR-171) in patients with hematologic malignancies. Clin Cancer Res 2009; 15: 7085-7091

60 Wäspi U, Blanc D, Winkler T, Rüedi P, Dudler R. Syringolin, a novel peptide elicitor from Pseudomonas syringae pv. syringae that induces resistance to Pyricularia oryzae in rice. Mol Plant Microbe Interact 1998; 11: 727-733

61 Groll M, Schellenberg B, Bachmann AS, Archer CR, Huber R, Powell TK, Lindow S, Kaiser M, Dudler R. A plant pathogen virulence factor inhibits the eukaryotic proteasome by a novel mechanism. Nature 2008; 452 : 755-759

62 Clerc J, Groll M, Illich DJ, Bachmann AS, Huber R, Schellenberg B, Dudler R, Kaiser $M$. Synthetic and structural studies on syringolin A and B reveal critical determinants of selectivity and potency of proteasome inhibition. Proc Natl Acad Sci USA 2009; 106: 6507-6512

63 Clerc J, Florea BI, Kraus M, Groll M, Huber R, Bachmann AS, Dudler R, Driessen C, Overkleeft HS, Kaiser M. Syringolin A selectively labels the $20 \mathrm{~S}$ proteasome in murine EL4 and wild-type and bortezomib-adapted leukaemic cell lines. ChemBioChem 2009; 10: 2638-2643

64 Amrein H, Makart S, Granado J, Shakya R, Schneider-Pokorny J, Dudler R. Functional analysis of genes involved in the synthesis of syringolin A by Pseudomonas syringae pv. syringae B301D-R. Mol Plant Microbe Interact 2004; 17: 90-97

65 Koguchi Y, Kohno J, Nishio M, Takahashi K, Okuda T, Ohnuki T, Komatsubara S. TMC-95A, B, C, and D, novel proteasome inhibitors produced by Apiospora montagnei Sacc. TC 1093. J Antibiot 2000; 53: 105-109

66 Kohno J, Koguchi Y, Nishio M, Nakao K, Kuroda M, Shimizu R, Ohnuki T, Komatsubara S. Structures of TMC-95A-D: novel proteasome inhibitors from Apiospora montagnei Sacc. TC 1093. J Org Chem 2000; 65: 990 995

67 Groll M, Koguchi Y, Huber R, Kohno J. Crystal structure of the 20S proteasome:TMC-95A complex: a non-covalent proteasome inhibitor. J Mol Biol 2001; 311: 543-548

68 Groll M, Götz M, Kaiser M, Weyher E, Moroder L. TMC-95-based inhibitor design provides evidence for the catalytic versatility of the proteasome. Chem Biol 2006; 13: 607-614

69 Inoue M, Zhai H, Sakazaki H, Furuyama H, Fukuyama Y, Hirama M. TMC-95A, a reversible proteasome inhibitor, induces neurite outgrowth in PC12 cells. Bioorg Med Chem Lett 2004; 14: 663-665

70 Sasse F, Steinmetz H, Schupp T, Petersen F, Memmert K, Hofmann H, Heusser C, Brinkmann V, von Matt P, Höfle G, Reichenbach H. Argyrins, immunosuppressive cyclic peptides from myxobacteria. I. Production, isolation, physico-chemical and biological properties. J Antibiot 2002; 55: 543-551

71 Nickeleit I, Zender S, Sasse F, Geffers R, Brandes G, Sörensen I, Steinmetz H, Kubicka S, Carlomagno T, Menche D, Gütgemann I, Buer J, Gossler A,
Manns MP, Kalesse M, Frank R, Malek NP. Argyrin A reveals a critical role for the tumor suppressor protein p $27^{\mathrm{kip} 1}$ in mediating antitumor activities in response to proteasome inhibition. Cancer Cell 2008; 14: 23-35

72 Pahl HL, Krauss B, Schulze-Osthoff K, Decker T, Traenckner EB-M, Vogt M, Myers C, Parks T, Warring P, Muhlbacher A, Czernilofsky A-P, Baeuerle $P A$. The immunosuppressive fungal metabolite gliotoxin specifically inhibits transcription factor NF-кB. J Exp Med 1996; 183: 1829-1840

73 Kroll M, Arenzana-Seisdedos F, Bacheelerie F, Thomas D, Friguet B, Conconi $M$. The secondary fungal metabolite gliotoxin targets proteolytic activities of the proteasome. Chem Biol 1999; 6: 689-698

74 Tsukamoto S, Tatsuno M, van Soest RWM, Yokosawa H, Ohta T. New polyhydroxy sterols: proteasome inhibitors from a marine sponge Acanthodendrilla sp. J Nat Prod 2003; 66: 1181-1185

75 Aoki S, Yoshioka Y, Miyamoto Y, Higuchi K, Setiawan A, Murakami N, Chen Z-S, Sumizawa T, Akiyama S, Kobayashi M. Agosterol A, a novel polyhydroxylated sterol acetate reversing multidrug resistance from a marine sponge of Spongia sp. Tetrahedron Lett 1998; 39: 6303-6306

76 Aoki S, Setiawan A, Yoshioka Y, Higuchi K, Fudetani R, Chen Z-S, Sumizawa T, Akiyama S, Kobayashi M. Reversal of multidrug resistance in human carcinoma cell line by agosterols, marine spongean sterols. Tetrahedron 1999; 55: 13965-13972

77 Tsukamoto S, Koimaru K, Ohta T. Secomycalolide A: a new proteasome inhibitor isolated from a marine sponge of the genus Mycale. Mar Drugs 2005; 3: 29-36

78 Su BN, Hwang BY, Chai H, Carcache-Blanco EJ, Kardono LBS, Afriastini IJ, Riswan S, Wild R, Laing N, Farnsworth NR, Cordell GA, Swanson SM, Kinghorn $A D$. Activity-guided fractionation of the leaves of Ormosia sumatrana using a proteasome inhibition assay. J Nat Prod 2004; 67: 19111914

79 Milacic V, Banerjee S, Landis-Piwowar KR, Sarkar FH, Majumdar AP, Dou $Q P$. Curcumin inhibits the proteasome activity in human colon cancer cells in vitro and in vivo. Cancer Res 2008; 68: 7283-7292

80 Chen D, Daniel KG, Chen MS, Kuhn DJ, Landis-Piwowar KR, Dou QP. Dietary flavonoids as proteasome inhibitors and apoptosis inducers in human leukemia cells. Biochem Pharmacol 2005; 69: 1421-1432

81 Kazi A, Daniel KG, Smith DM, Kumar NB, Dou QP. Inhibition of the proteasome activity, a novel mechanism associated with the tumor cell apoptosis-inducing ability of genistein. Biochem Pharmacol 2003; 66: 965-976

82 Wan SB, Landis-Piwowar KR, Kuhn DJ, Chen D, Dou QP, Chan TH. Structure-activity study of epi-gallocatechin gallate (EGCG) analogs as proteasome inhibitors. Bioorg Med Chem 2005; 13: 2177-2185

83 Yang $H$, Shi G, Dou QP. The tumor proteasome is a primary target for the natural anticancer compound withaferin A isolated from "Indian Winter Cherry". Mol Pharmacol 2007; 71: 426-437

84 Yang H, Chen D, Cui QC, Yuan X, Dou QP. Celastrol, a triterpene extracted from the Chinese "Thunder of God Vine," is a potent proteasome inhibitor and suppresses human prostate cancer growth in nude mice. Cancer Res 2006; 66: 4758-4765

85 Petroski MD, Deshaies RJ. Function and regulation of cullin-RING ubiquitin ligases. Nat Rev Mol Cell Biol 2005; 6: 9-20

86 Bernassola F, Karin M, Ciechanover A, Melino G. The HECT family of E3 ubiquitin ligases: multiple players in cancer development. Cancer Cell 2008; 14: 10-21

87 Vassilev LT. MDM2 inhibitors for cancer therapy. Trends Mol Med 2007; 13: 23-31

88 Vazquez A, Bond EE, Levine AJ, Bond GL. The genetics of the p53 pathway, apoptosis and cancer therapy. Nat Rev Drug Discov 2008; 7 : 979-987

89 Vassilev LT, Vu BT, Graves B, Carvajal D, Podlaski F, Filipovic Z, Kong N, Kammlott $U$, Lukacs C, Klein C, Fotouhi N, Liu EA. In vivo activation of the 553 pathway by small-molecule antagonists of MDM2. Science 2004; 303: 844-848

90 Ooi MG, Hayden PJ, Kotoula V, McMillin DW, Charalambous E, Daskalaki E, Raje NS, Munshi NC, Chauhan D, Hideshima T, Buon L, Clynes M, O'Gorman P, Richardson PG, Mitsiades CS, Anderson KC, Mitsiades N. Interactions of the $\mathrm{Hdm} 2 / \mathrm{p} 53$ and proteasome pathways may enhance the antitumor activity of bortezomib. Clin Cancer Res 2009; 15: 71537160

91 Duncan SJ, Grüschow S, Williams DH, McNicholas C, Purewal R, Hajek M, Gerlitz M, Martin S, Wrigley SK, Moore M. Isolation and structure elucidation of chlorofusin, a novel p53-MDM2 antagonist from a Fusarium sp. J Am Chem Soc 2001; 123: 554-560 
92 Qian WJ, Wei WG, Zhang YX, Yao ZJ. Total synthesis, assignment of absolute stereochemistry, and structural revision of chlorofusin. J Am Chem Soc 2007; 129: 6400-6401

93 Lee SY, Clark RC, Boger DL. Total synthesis, stereochemical reassignment, and absolute configuration of chlorofusin. J Am Chem Soc 2007; 129: 9860-9861

94 Clark RC, Lee SY, Boger DL. Total synthesis of chlorofusin, its seven chromophore diastereomers, and key partial structures. J Am Chem Soc 2008; 130: 12355-12369

95 Duncan SJ, Williams DH, Ainsworth M, Martin S, Ford R, Wrigley SK. On the biosynthesis of an inhibitor of the p53/MDM2 interaction. Tetrahedron Lett 2002; 43: 1075-1078

96 Tsukamoto S, Yoshida T, Hosono H, Ohta T, Yokosawa H. Hexylitaconic acid: a new inhibitor of p53-HDM2 interaction isolated from a marine-derived fungus, Arthrinium sp. Bioorg Med Chem Lett 2006; 16: 69-71

97 Nakahashi A, Miura N, Monde K, Tsukamoto S. Stereochemical studies of hexylitaconic acid, an inhibitor of p53-HDM2 interaction. Bioorg Med Chem Lett 2009; 19: 3027-3030

98 Stoll R, Renner C, Hansen S, Palme S, Klein C, Belling A, Zeslawski W, Kamionka M, Rehm T, Mühlhahn P, Schumacher R, Hesse F, Kaluza B, Voelter W, Engh RA, Holak TA. Chalcone derivatives antagonize interactions between the human oncoprotein MDM2 and p 53. Biochemistry 2001; 40: 336-344

99 Devicenzo R, Scambia G, Panici PB, Ranelletti FO, Bonanno G, Ercoli A, Dellemonache F, Ferrari F, Piantelli M, Mancuso S. Effect of synthetic and naturally occurring chalcones on ovarian cancer cell growth: structure-activity relationships. Anticancer Drug Des 1995; 10: 481490

100 Issaeva N, Bozko P, Enge M, Protopopova M, Verhoef LG, Masucci M, Pramanik A, Selivanova G. Small molecule RITA binds to p53, blocks p 53HDM-2 interaction and activates p 53 function in tumors. Nat Med 2004: 10: 1321-1328

101 Sekizawa R, Ikeno S, Nakamura H, Naganawa H, Matsui S, Iinuma H, Takeuchi $T$. Panepophenanthrin, from a mushroom strain, a novel inhibitor of the ubiquitin-activating enzyme. J Nat Prod 2002; 65: 1491-1493

102 Tsukamoto S, Hirota H, Imachi M, Fujimuro M, Onuki H, Ohta T, Yokosawa $\mathrm{H}$. Himeic acid A: a new ubiquitin-activating enzyme inhibitor isolated from a marine-derived fungus, Aspergillus sp. Bioorg Med Chem Lett 2005; 15: 191-194

103 Yang Y, Kitagaki J, Dai RM, Tsai YC, Lorick KL, Ludwig RL, Pierre SA, Jensen JP, Davydov IV, Oberoi P, Li CC, Kenten JH, Beutler JA, Vousden KH, Weissman AM. Inhibitors of ubiquitin-activating enzyme (E1), a new class of potential cancer therapeutics. Cancer Res 2007; 67: 94729481

104 Pickart CM, Fushman D. Polyubiquitin chains: polymeric protein signals. Curr Opin Chem Biol 2004; 8: 610-616

105 Sun L, Chen ZJ. The novel functions of ubiquitination in signaling. Curr Opin Cell Biol 2004; 16: 119-126

$106 \mathrm{Li} W$, Ye Y. Polyubiquitin chains: functions, structures, and mechanisms. Cell Mol Life Sci 2008; 65: 2397-2406

107 Andersen PL, Zhou H, Pastushock L, Moraes T, McKenna S, Ziola B, Ellison MJ, Dixit VM, Xiao W. Distinct regulation of Ubc13 functions by the two ubiquitin-conjugating enzyme variants Mms2 and Uev1A. J Cell Biol 2005; 170: 745-755

108 Laine A, Topisirovic I, Zhai D, Reed JC, Borden KLB, Ronai Z. Regulation of p53 localization and activity by Ubc13. Mol Cell Biol 2006; 26: 89018913

109 Tsukamoto S, Takeuchi T, Rotinsulu H, Mangindaan REP, van Soest RWM, Ukai K, Kobayashi H, Namikoshi M, Ohta T, Yokosawa H. Leucet- tamol A: a new inhibitor of Ubc13-Uev1A interaction isolated from a marine sponge, Leucetta aff. microrhaphis. Bioorg Med Chem Lett 2008; 18: 6319-6320

110 Kong F, Faulkner DJ. Leucettamols A and B, two antimicrobial lipids from the calcareous sponge Leucetta microraphis. J Org Chem 1993; 58: $970-971$

111 Dailisay DS, Tsukamoto S, Molinski TF. Absolute configuration of the $\alpha, \omega$-bifunctionalized sphingolipid leucettamol A from Leucetta sp. by deconvoluted exciton coupled CD. J Nat Prod 2009; 72: 353-359

112 Topisirovic I, Gutierrez GJ, Chen M, Appella E, Borden KLB, Ronai ZA. Control of p53 multimerization by Ubc13 is JNK-regulated. Proc Natl Acad Sci USA 2009; 106: 12676-12681

113 Deveraux Q van Nocker S, Mahaffey D, Vierstra R, Rechsteiner M. Inhibition of ubiquitin-mediated proteolysis by the Arabidopsis 26S protease subunit S5a. J Biol Chem 1995; 270: 29660-29663

114 Husnjak K, Elsasser S, Zhang N, Chen X, Randles L, Shi Y, Hofmann K, Walters KJ, Finley D, Dikic I. Proteasome subunit Rpn13 is a novel ubiquitin receptor. Nature 2008; 453: 481-488

115 Schreiner P, Chen X, Husnjak K, Randles L, Zhang N, Elsasser S, Finley D, Dikic I, Walters KJ, Groll M. Ubiquitin docking at the proteasome through a novel pleckstrin-homology domain interaction. Nature 2008; 453: 548-552

116 Elsasser S, Finley D. Delivery of ubiquitinated substrates to protein-unfolding machines. Nat Cell Biol 2005; 7: 742-749

117 Verma R, Oania R, Graumann J, Deshaies RJ. Multiubiquitin chain receptors define a layer of substrate selectivity in the ubiquitin-proteasome system. Cell 2004; 118: 99-110

118 Lavelle F, Zerial A, Fizames C, Rabault B, Curaudeau A. Antitumor activity and mechanism of action of the marine compound girodazole. Invest New Drugs 1991; 9: 233-244

119 Tsukamoto S, Yamashita K, Tane K, Kizu R, Ohta T, Matsunaga S, Fusetani $N$, Kawahara H, Yokosawa H. Girolline, an antitumor compound isolated from a sponge, induces G2/M cell cycle arrest and accumulation of polyubiquitinated p53. Biol Pharm Bull 2004; 27: 699-701

120 Verma R, Peters NR, D'Onofrio M, Tochtrop GP, Sakamoto KM, Varadan $R$, Zhang M, Coffino P, Fushman D, Deshaies RJ, King RW. Ubistatins inhibit proteasome-dependent degradation by binding the ubiquitin chain. Science 2004; 306: 117-120

121 Guterman A, Glickman MH. Complementary roles for Rpn11 and Ubp6 in deubiquitination and proteolysis by the proteasome. J Biol Chem 2004; 279: 1729-1738

122 Komander D, Clague MJ, Urbe S. Breaking the chains: structure and function of the deubiquitinases. Nat Rev Mol Cell Biol 2009; 10: 550563

123 Mullally JE, Moos PJ, Edes K, Fitzpatrick FA. Cyclopentenone prostaglandins of the $J$ series inhibit the ubiquitin isopeptidase activity of the proteasome pathway. J Biol Chem 2001; 276: 30366-30373

124 Verbitski SM, Mullally JE, Fitzpatrick FA, Ireland CM. Punaglandins, chlorinated prostaglandins, function as potent Michael receptors to inhibit ubiquitin isopeptidase activity. J Med Chem 2004; 47: 2062 2070

125 Colland F, Formstecher E, Jacq X, Reverdy C, Planquette C, Conrath S, Trouplin V, Bianchi J, Aushev VN, Camonis J, Calabrese A, Borg-Capra C, Sippl W, Collura V, Boissy G, Rain JC, Guedat P, Delansorne R, Daviet L. Small-molecule inhibitor of USP7/HAUSP ubiquitin protease stabilizes and activates p 53 in cells. Mol Cancer Ther 2009; 8: 2286-2295

126 Milano A, Iaffaioli RV, Caponigro F. The proteasome: a worthwhile target for the treatment of solid tumours? Eur J Cancer 2007; 43: 11251133 